\title{
History as Contemporary History in the Thinking of Benedetto Croce
}

\author{
Nicola Conati \\ Department of Humanities, University of Trento, Trento, Italy \\ Email: nicola.conati@gmail.com
}

Received 12 January 2015; accepted 30 January 2015; published 3 February 2015

Copyright (C) 2015 by author and Scientific Research Publishing Inc.

This work is licensed under the Creative Commons Attribution International License (CC BY).

http://creativecommons.org/licenses/by/4.0/

cc) (†)

Open Access

\begin{abstract}
In this brief consideration of mine, trying to remain as faithful as possible to the texts taken into exam, I will first try to introduce the concept of history as contemporary history in the thinking of Benedetto Croce, whereas the second part of the reasoning will point toward proving and meditating on how such concept crosses the whole philosophical system of the Italian intellectual. What does contemporary history mean according to Benedetto Croce? Why is the spirit of the historian fundamental in the description of this concept? What kind of connection exists between story and contemporary history? What does pathology of history mean? How does the concept of contemporary history relate to that of awareness, of finished and thinking? These are but a few of the questions to which I tried to find an answer with this essay.
\end{abstract}

\section{Keywords}

Benedetto Croce, History, Philosophy of History, Historical Knowledge, Contemporary History, Pathology of History, Heidegger, Rosmini, Idealism

\section{Introduction}

I would like to begin my consideration by taking into account "Storia, cronaca e false storie”, a brief 1912 deliberation originally born as a "memoir" for the Accademia Pontiniana of Naples, which will later merge into the 1917 "Teoria e storia della storiografia” (although the first edition was published in Germany in 1915). Evidences concerning the composition of this piece of writing lead us in German territory, where the thoughts of the philosopher circulated among the entire academic environment. In 1909, the publishing house Mohr of Tubinga encourages Croce to write a manual of Philosophy of History, which he will replace with his very own "Teoria e storia della storiografia”, marking the ultimate estrangement from the Philosophy of History. As proof, in 1912 he wrote to Medicus that "in no way I could write a handbook of Philosophy of History, because I deny it: you 
cannot do a treatise or handbook with a negative thesis” (Picardi, 2002: pp. 34-38).

That being said, Croce establishes the problem of history as contemporary history in the very first pages. He states that "contemporary history" usually refers to a near past: if we were to ask someone on the street what they mean by contemporary history, it is very likely that their answer will refer to historical events happened between the second post war period and today. In actuality contemporary history is that which begins in the moment I perform an action, it is defined as the actual present: he states that, while writing these pages, he is within the boundaries of contemporary history. On the contrary, the history which is defined as "non-contemporary" or "past history" is what we find in front of ourselves, a history that is already fully formed and, in some sense, one we cannot partake in.

Either way, this must not be excluded from the general conception of history. Why? Because the entirety of history is in a way contemporary, for the fact that it is present inside the mind of the historian: it makes a specific instance identifiable as "contemporary". For example, let us suppose that it is true that the spirit of today's world is that of the United States of Europe: it makes contemporary that part of European history in which Europe was present as an empire. According to this idea, Carlo V is our peer, although he lived in the 1500s, since he is the one who reunited Europe. In that case, the opposition was represented by the Districts, which in this situation may be compared to Padania or any other nationalist ideology. History that does not belong to this specific instance is not contemporary history; it is the present that makes history contemporary.

\section{The Relationship between History and Spirit}

As a matter of fact, it is interesting to remember how an important philosopher such as Carl Schmitt, wrote in "L'epoca delle neutralizzazioni e spoliticizzazioni" that "from Hegel on, and in the best fashion Benedetto Croce, they made us realize that every historical knowledge is knowledge of the present, which means that it finds its source in the present, since every spirit is just present” (Schmitt, 1932: p. 167).

Therefore, if contemporary history is like that because it "vibrates inside the historian's mind" (Croce, 2002), from life itself will rise the one we are used to call non-contemporary life, for the fact that only the interest toward contemporary history is present and it can drive me to get involved with something past. This is the reason that lays at the basis of history as life's teacher: "every true story is contemporary history (...) contemporaneity is not a class of history, rather it is the intrinsic aspect of every story. We have to conceive the close relationship between history and life as one” (Croce, 2012: pp. 59-60). History is contemporary when it is tied to life not in an abstract way, but rather when it is both tied and distinct at the same time. Past history is contemporary history in the sense that, through historical research, we manage to make past history as well actual, present and contemporary. This happens because the developments in past history have implications in present history: hence, non-contemporary history rises from life, for the fact that it originates from an interest toward present life, too.

Thereof history cannot be acted or thought of without a human mind thinking of it or acting it: history is history of an immanent spirit, which cannot rise from metaphysics or Philosophy of History where the path has already been traced. This consideration requires a mention of the topics of disease and pathology that will be analyzed further on. The fact that Croce conceives history as the development of a story whose protagonist is an immanent spirit, so that nothing can precede history or decide what the order of things will be, causes him to debate with some fundamental philosophical figures. Consider the concept of disease according to Kierkegaard: it is about an ontological disease, rather than a historical one; in this sense, man is ontologically ill, that is before any history. Of the same opinion, we find Sartre, who in "La Nausea" speaks of an ontological disease, which can be overcome only by art. Take the character of Roquentin, a history student whose solitude brings him to understand that men constantly give a noble and high sense to their own existence. This awareness makes the protagonist nauseous of himself and the world around him, acknowledging that only art can soothe this disease (Sartre, 2010). The French writer accepts Kierkegaard's premise according to which the artist is sick because the disease is ontological. The difference between him and Croce, we will see, is enormous since the Italian philosopher talks about a moral disease, in which the man who makes history is involved.

\section{The Role of Documents}

Once you come to this point, it is relevant to analyze a query that was asked by Croce in order to better explain the matter: do Greece and Hellenic spirit have to be part of this new modern empire? In this case, are we speaking of contemporary history? The relationship with the Greek civilization, if it is a contemporary one, thus 
meant as something deeply tied to my being like a love that I am nurturing or a danger that looms over my existence, allows Greece to be tied to Europe and to the context we are offering: "in that case, the Hellenic life is present inside of me" (Croce, 2012: p. 60). Consider a current example: if we consider contemporary the crisis we are living now, the same will be for the other crises recalled by it. Then, however, how can The Crash of 1929 be conceived as contemporary history? According to Croce, only in one way: through documents; they are the medium through which we make it contemporary. History is contemporary in its relationship with the document: we might say that, from an insider point of view, history is contemporary to life, while from an outsider point of view it is made alive through the documents. The spirit of time, or rather the historical development, will rise from this relationship between document and life. It is nothing else but the spirit of today, it is not something past and imaginary. If there were no relationship between document and life, history would not be controllable. Besides, resuming the matter touched earlier, the same pathology arises when this relationship is broken, leaving only empty words: "what remains is no longer history, and we may keep calling it history only in the same way we call “man” a man’s corpse, for what remains is nothing” (Croce, 2012: p. 63).

\section{Contemporary History Is Not a Simple Story}

At this point, Croce suggests a distinction between history and story, between contemporary history and dead or past history: if history is contemporary, we have to separate it from mere story. Contrary to the general belief, this distinction does not rely only on the fact that history summarizes the most important events while story those most ordinary: the crucial point does not lie in the fact that the first is about the crisis and the second is about Balotelli's latest tweet. But then, what is the relationship existing between history and story? As I said, contemporary history is tied to life, to the living: contemporary history is no heaven and its parts of dead history maintain the possibility to live. Story is conceived as a non-living history, from which you can only make a dead story. So, in the relationship between history and story, which of the two comes first? From this point, it is important to acknowledge the ocean that divides logical approach and chronological order: the logical approach is the historical one (history coming before story), while story is not logical, rather it is only of chronological kind. We might say that every history becomes story when it is no longer thought, but only remembered in abstract words.

In this respect, Croce digresses into the historical novel: it has nothing in common with the historical reality; it contains truths that are not present in the novel. Now, if the historian establishes a link with the document, what is the connection established by the writer of the historical novel? Probably, it is the one with a non-living event in the spirit of the historian.

Now it appears clear that the document conceived as detached from life becomes just a "thing" and, in turn, history detached from the live document becomes just story. So, do these dead documents or stories exist or not?

In a way, they do not because the things outside the spirit do not exist; as a matter of fact, we know that story exists as an act of will: just like the corpse is at any rate a process of vital creation, those dead documents exist as well since they are expressions of new life. Transcribing empty stories and collecting dead documents is an act of life; the moment will come in which they will reproduce past history in our spirit, making it present. Many documents that are mute to us (what, to us, is now story) will restart speaking, coming back to life. With this in mind, it will be necessary to remember that spirit itself is history: spirit already carries in itself the whole history and it would relive its history even without those external things, which are stories and documents. Nevertheless, those external things are instruments and preparatory acts that he does in order to activate inner revival.

\section{The Pathologies of History}

From this point, Croce evaluates the existence of some mental forms, such as history, story, philology, which may move from physiology, that is from being real and rational, to pathology. In summary Croce is asking himself: what are the diseases of history? He points out three of them: philological history, poetic history and oratory history.

\subsection{Philological History}

As far as philological history is concerned, Croce states that he feels enormous respect toward philologists (by the way, profound philological studies were the starting point of his researches). The philosopher explains the 
reason of his position against philological history: it is reduced to the transfer of different books or different parts of many books, into a single book. Philological history is a compilatory thesis, because in it the relationship between document and historian's mind was broken. It spares the effort of analyzing more books, since they are presented in a single one (for example, a philosophy handbook). They do not contain any historical thought (the philosophy handbook has no historical thought): philological history is a compilatory one because the presented entries are placed in an unrelated way in respect to the tale we are telling. Once acknowledged that it brings stories and documents, but no histories, what are the three flaws of philological history? The first one is traced to the idea and claim of composing history through documents and tales (stories that are buffed up and reorganized, truth-less stories). The second is the belief that it has any sort of truth; story refers to its own authority and not to its own truth. The third and final flaw is that it is not interesting neither, being not true, and therefore in contradiction with true history: only critical history is true history. Philological history is untrue because it is not interesting; this term shows a determination of practical and ethical kind.

The fact that philological history proceeds without truth and passion, explains the reasons of the vivid conflict between philological historians and historians in the strictest sense of the word. The best example of such diatribe can be found in Bolingbroke's 1751 "Letters on the study of history", in which he defines erudition as magnificent ignorance (Croce, 2012: p. 79). However, we should acknowledge that simple philosophers, poor scholars, archaeologists, bring only positive factors and, were they to disappear, we should have to replace them immediately (Croce, 2006).

Philological history perishes not because of its opponents, rather because of its enthusiasts that destroy it by conceiving it as detached from life, as mere exercise. The passage concludes with his friend's irony who, after reading a handbook of ancient Rome history, said to be the mightiest among philosophers because they come to the conclusion of knowing nothing by constant efforts.

\subsection{Poetic History}

As stated previously, philological history is the history which is not interesting, in the sense that it has no practical and ethical interest; poetic history stands as critique of philological history and it is not about an interest of thinking, but rather of feeling. Examples are given by "affectionate” biographies, saints' biographies, but also those satirical of hated ones or patriotic stories, or the tale told by an anti-Semite that depicts the Jew everywhere. It is not history truly lived, but somehow fomented by feeling, on one side by the corrupt political class and on the other by the angry people: I analyze this situation through the pretty or non-pretty, not through the true and non-true. Poetic history is at the same time history of what is pretty and of what is not, while contemporary history is history of what is true and what is false. The value of feeling concerns life, while the value of history lies in the values of thinking. Philological history is both an objective and neutral history: in this case fantasy is mixed in and it goes beyond a mere empty description. Nonetheless, a misunderstanding remains: this fantasy must not be separated from historic synthesis, distinguishable from pure poetic fantasy, bound to thought, and for the sake of thought itself.

Already it appears clear how contemporary history presumes subjective thinking, a rise of the historian in both thought and action; contemporary history presumes the exaltation of historic subjectivity, thinking or acting, as subjectivity of thought.

\subsection{Oratory History}

The third kind of pathology of history is to be found mainly in ancient times, in what was defined as oratory or rhetoric history. It presumed to teach philosophy through example: to move someone to virtue, to institute the best possible political or military organizations, to delight; and it is found also nowadays (often translating into morals or educational systems).

The structure of rhetoric history presumes a clearly preformed history (poetic or philological) which is narrated to a practical end. In any case, we speak of practical act, which uses history as a mean; oratory history always comprises two elements: history, and a practical end, which lead to a practical act. It takes the shape of a history apart, as it is not only a simple history of emotions: first, it has an end to meet and second, such an end is not imposed from the outside, but coincides with the very essence of this history: we should consider it as halfway between poetic and practical.

Once identified the pathologies of history, Croce states that: "History is (ideally) contemporary" (Croce, 2012: 
p. 98), as it becomes such in thinking, through the actions of the historian whose end is to reestablish the historic reality of a determined dimension: this history is contemporary in thought. Therefore, if I want to make history, I must necessarily make use of subjective thinking, in order to be able to comprehend and then act upon that very thought.

\subsection{The Role of Pathologies of History}

It is now important to understand how those pathologies, previously spoken about, are not deconstructed: they could be if realized as facts, yet they are simple presumptions. This mistake, actually, is nothing but the negative or dialectic moment of the spirit, necessary for the realization of the positive moment. The perfect example is found within us: while examining the historic subject, fondness and aversion arise (our poetic history), along with our intentions as practical human beings (our oratory history) and our chronicle memories (our philological history). As we go beyond these, we find ourselves in possession of a new and deep historic truth: thus is history affirmed, distinguished from non-history by overcoming the dialectical moments born from them.

\section{Knowledge}

At this stage, the issue of knowledge is opened. We must recognize how narrow our knowledge actually is, especially compared to our thirst for it: the only way out seems to be focusing on that detail which answers a determined problem, and which constitutes the living and acting history: that is, contemporary history, as "no fact remains unknown, in the act of being carried out” (Croce, 2012: p. 107).

In this regard, Croce quotes Tolstoy, criticized as the perfect example of those writers of historic novellas for his decision of narrating battles through hearsay, voices and tales: Croce stresses how nobody can predict the outcome of a battle, or even know how it actually played out because the very moment it is over, a legendary and artificial account spreads around, and only a fool would take it as historical.

Croce states that in any given moment, we know every side of history that we care to know, and what is left out doesn't matter to us: for this reason we don't possess the prerequisites to know it.

What is left out, we will know once it is of interest to us: it is nothing but the eternal ghost of la "cosa in sè”", the fantastic projection of our endless process of acting and knowing.

The historian doesn't stand outside the thinking process, he stands indeed as the thinking process, which may never go beyond its own historic situation.

\subsection{The Historic Knowledge as the Entirety of Knowledge}

Before concluding this consideration, I would like to hint to another work by Croce, to better comprehend in detail how he imagined knowledge. It is the year 1938, the title is "La storia come pensiero e come azione", an interesting work where Croce upholds his fundamental philosophical system, built in the first 15 years of the century, which he had abandoned after 1920 after studying aesthetics. According to my point of view, this is an essential work, as in it, Croce reaffirms the principle of historic knowledge as the entirety of knowledge. He says that every judgment is, doubtlessly, a historic judgment or history: if this judgment is relationship of subject and predicate, the subject being judged will always be a historic fact in continuous evolution. Even inanimate objects are considered in this (as per the example of the rock I move from my path).

From this statement we can infer another consequence: historical judgment is not only an order of knowledge, but knowledge itself, the form filling the whole cognitive field, leaving nothing out of its scope: it is indeed undeniable that any cognitive process is bound to life, or action. Croce's absolute historicism clearly shows here.

\subsection{The Historic Knowledge and the Natural Science}

Yet now we could ask ourselves: what role will natural science and philosophy take? Even natural science is based upon the practical needs of living, and to their fulfillment: the idea was introduced by Francis Bacon (he who merged medicine and history) according to Croce, who here proposes an interesting passage, with an ex-

\footnotetext{
${ }^{1}$ The term is hardly translatable form the original Italian. To better understand it, in other area of philosophy such an expression is synonymous with "noumenon". I took the liberty of either translating it as "his reasoning", mainly for purposes of semantics and better sentence flow, or leaving it untranslated.
} 
ample. One may memorize the entirety of the medical knowledge, every kind of sickness and their characteristics but, quoting Montaigne "it's good for Galeno, not the sick" (Croce, 2002: p. 27). This is so because we know little in this way, as little as someone who analyzes history through conscience. Knowledge is not knowing every kind of sickness, knowledge is the historic knowledge of the sick person, knowledge of an individual in relation to all the others. Why? Because only in relation to others can I recognize him as sick.

Therefore, historic knowledge is not in contrast with natural science as the latter also works in the world. What about philosophy though? Traditional philosophy has its eyes trained on the sky: following this, it is based on a dualistic conception of a reality transcending reality, of a metaphysics upon physics: its peculiarity is to have something of the divine, where God's name is indifferently God or Matter, Idea or Will, but always a principle transcending the world, historically speaking, and in opposition to an inferior phenomenal reality.

Now though, historical thinking has rendered traditional philosophy historic by going beyond its dialectically unresolved dualism: all its doctrines and concepts have been interpreted as historical facts, born of fulfilled and unfulfilled needs.

Following this process of making philosophy into history, Croce affirms how the former has lost its autonomy, that is the metaphysical aspect: what it is now is not philosophy anymore, but history: this historic philosophy is defined in its core by the principle of identity between individual and universal.

\section{The Finite Is Ideal}

\subsection{The Knowledge of Universal History}

Now I would like to get back to the main point of this paper, and introducing by doing so the concept that it is necessary to surpass any dualism between history and "sopra-storia"”2. First, this surpassing is an idea bound to Croce's way of interpreting universal history and the concept of finite as ideal. Having analyzed the concepts of knowledge and history, and thus acknowledging how we can know nothing but the finite and the particular, must we renounce the knowledge of universal history? Croce's answer is affirmative, but he also reminds us that we are renouncing something which we could not hope to get, and therefore should not be of grievance to us: even universal history is not a fact, but a pretense. Indeed if we were to be watchful, we could see how universal history always reveals particular histories or in other words, histories born of a specific interest and hinged on a single problem.

It is now clear how the gaze of God, watching History as-it-becomes, is a mere fantastic projection, as it is a finite gaze repeated an infinite number of times: to negate universal history doesn't mean to negate the knowledge of the universal in history.

\subsection{Beyond the Separation between Finite and Infinite}

From this point forward, Croce develops his concept of finite as ideal. The finite gaze is limited not by fantastic projection as much as by thought, and for this reason thought is considered universal. The finite only exists in abstract: history deals with the subject of thought, something ideal, which Croce always considers an immanent ideal, impossible to figure as real outside of its historical situation.

We can only operate with, and know the finite: la "cosa in sè”, there is no external gaze which sees history before it is such. This gaze must not exist, otherwise we should have to acknowledge a separation between essence and existence in history: if such a separation were to be admitted, then we should speak of Philosophy of History. History is thought, and as such is thought of the universal in its concreteness, it is infinite thought of something which is determined, finite: the mere finite and particular only exists in abstract, the reign of the individual. The concept introduced by Croce is, if we believe the separation between finite and infinite, known history and as a thing in itself, we cannot recognize history as it is.

\section{The Contemporary History and the Historic Philosophy}

Furthermore, he affirms that by failing to tell history from philosophy we are left entangled in a discourse without exit, and a whole series of unresolvable dualisms. However, if history gains the knowledge of the eternal present, it reveals itself as being one with philosophy, which is of its own the thought of the eternal present.

${ }^{2}$ The term refers to the concept of a stage above that of simple history. 
Croce also states that if history is correctly interpreted, it negates the need for a universal history and thus, immanent philosophy is identical to history and eliminates the idea of a universal philosophy. In conclusion history, in becoming contemporary history, as philosophy becoming historic philosophy, frees itself from the burden of being unable to know what is unknown, as it was and will be known, and philosophy from that of never reaching an absolute truth.

This critique of dualism is directed at religion too. We are pilgrims wandering in this world in preparation of the eternal life, seen as opposed to history: to reach the eternal present, one must go beyond such chronology. Religion, when not philosophically intended is based on the dualism between truth of fact and reason, finite and infinite, thought and reality, rational and real: all these options are seen as in opposition, not linked one to the other. In what the philosopher calls the dualistic vision of history and philosophy, this study is built on the premise that there is in fact a thought which sees the concatenation of facts.

\section{Croce, Heidegger, Rosmini}

In this regard, I would like to conclude by citing two authors. First, it appears clear that Croce opposes the view Heidegger introduces in "Essere e Tempo": what Heidegger describes is not a subject of thinking, but one of life, of existence. He says that the subject encompassing being is one of life and existence indeed: what it comprises is not a product of its own thinking as much as the revelation of being through this existence and life. In truth, the subject is just the link to what being means: the "existing" is not a thinking subject but the vehicle with which being reveals itself. Now, if the existing subject is what we just said it is, being is then something which foreruns real history.

Secondly, I would hint at the famous debate against Rosmini, and analyze the first chapter of the 1906 "Saggio sullo Hegel" (redacted by Croce the previous year, where he translates the "Enciclopedia delle scienze filosofiche"), titled "La dialettica o sintesi degli opposti". The debate originated from an objection raised by Rosmini on Hegel, about the concept of dialectics (Croce, 2007). We know that the German philosopher did recognize the importance of the negative moment as the impulse which starts the entire dialectic mechanism, and the fact that the first moment must be in the becoming, not in the thesis, as it already comprises thesis and antithesis. Indeed, if we were to start from an empirical analysis, the synthesis would be the third element, while according to both Hegel and Croce it is the first. The starting point is the becoming, which I conceive as antithesis of being and not being. The becoming precedes this, and the terms being and not being are conceivable only in this becoming. Now, this becoming is understood as a dynamic initiated by a negative, a lack of: it is interpreted as a shortcoming which starts the becoming of good. Having explained this, if the first moment is neither being nor nothing, but the becoming, it comprises both being and not being: in this case, Croce affirms how the becoming, in Hegel, resembles the concept of Dionysian in Nietzsche. Thus, philosophy as a universal concreteness is called Dionysian. Such an element, which is in fact the becoming, scares the feeble thinkers, amongst whom Croce places Rosmini.

On the other side, what does Rosmini say about Hegel? He criticizes Hegel by stating that history must be observed from the outside. The becoming has to observed by some mind; the mind which oversees, knows and sustains the becoming must not be mistaken with the becoming's own mind. Furthermore, what reason could bring one to negate oneself? If madness is the negation of identity, how would one explain the mad idea of negating oneself? The important point for our discussion is that madness is the attempt of negating the positive, therefore the negative or antithesis. Rosmini also states that by placing the becoming as the first moment, he turns the being mad or opens the doors to madness in everything.

Such a discourse prompts Croce to answer by affirming that Rosmini is stuck in "his reasoning": he cannot agree with Rosmini because according to the latter madness is the reason of history not observed from the outside while according to the former the same history is comprehensible only with a wider scoped gaze, one encompassing history in itself through a logic of instincts and not of dualistic elements. From this we could open the debate of spirit in relation to pathology and the concept of Hegelian dialectics in Croce's work. Perhaps another time.

\section{Acknowledgements}

I would like to take this opportunity to thank Professor Nestore Pirillo and Professor Raffaele Russo for their passion-driven teaching. 


\section{References}

Croce, B. (2002). La storia come pensiero e come azione (a cura di M. Conforti con una nota al testo di G. Sasso). Napoli: Bibliopolis.

Croce, B. (2006). Contributo ad una critica di me stesso (a cura di F. Audisio). Napoli: Bibliopolis.

Croce, B. (2007). Saggio sullo Hegel. Napoli: Bibliopolis.

Croce, B. (2012). Polemica sulla storia (a cura di A. Musci). Roma: Edizioni di Storia e Letteratura.

Picardi, R. (2002). Carteggio Croce-Medicus. Napoli: Istituto Italiano per gli Studi Storici.

Sartre, J.-P. (2010). La nausea. Torino: Einaudi.

Schmitt, C. (1932). L’epoca delle neutralizzazioni e delle spoliticizzazioni da Il concetto di “politico”. In Le categorie del "politico" (1998), Bologna: Il Mulino. 
Scientific Research Publishing (SCIRP) is one of the largest Open Access journal publishers. It is currently publishing more than 200 open access, online, peer-reviewed journals covering a wide range of academic disciplines. SCIRP serves the worldwide academic communities and contributes to the progress and application of science with its publication.

Other selected journals from SCIRP are listed as below. Submit your manuscript to us via either submit@scirp.org or Online Submission Portal.
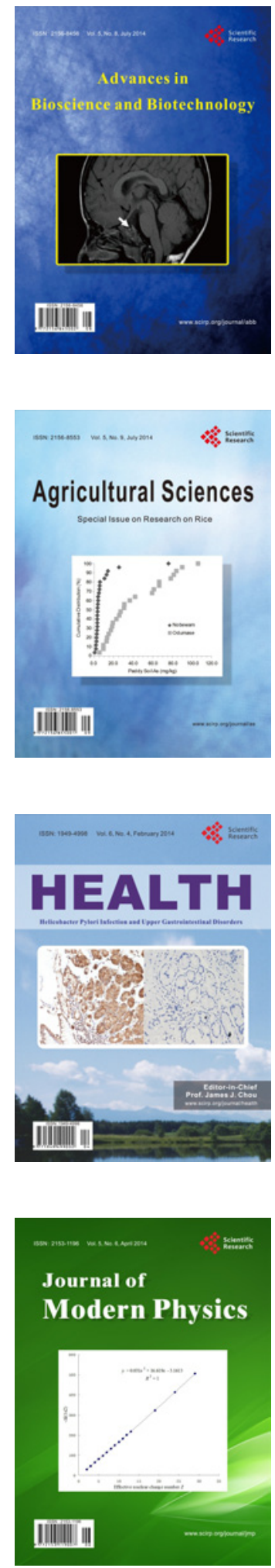
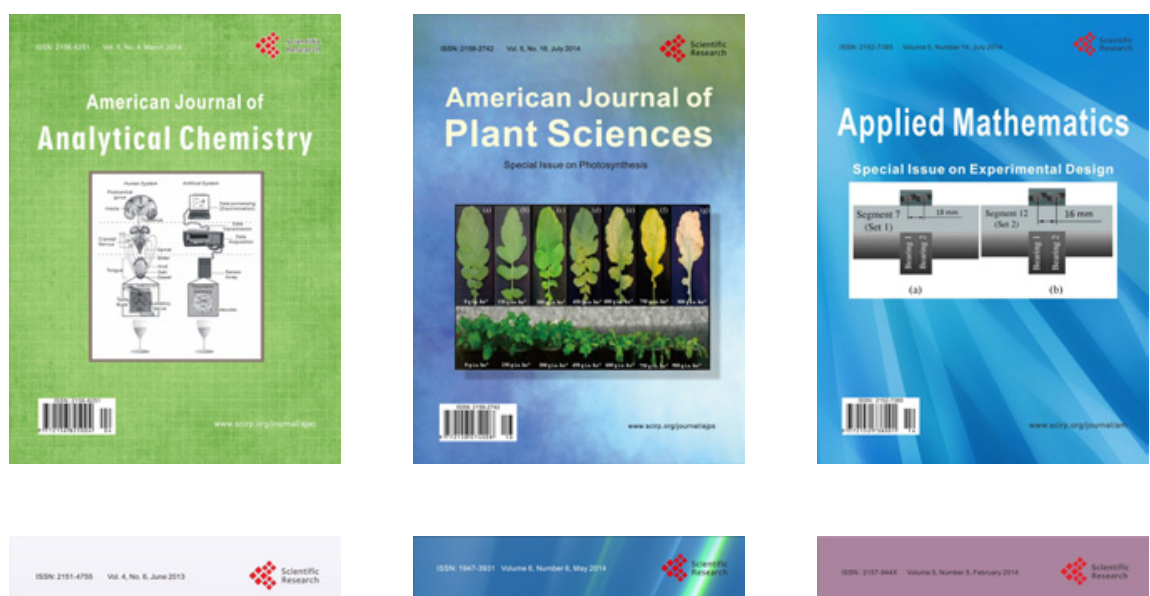

Creative Education
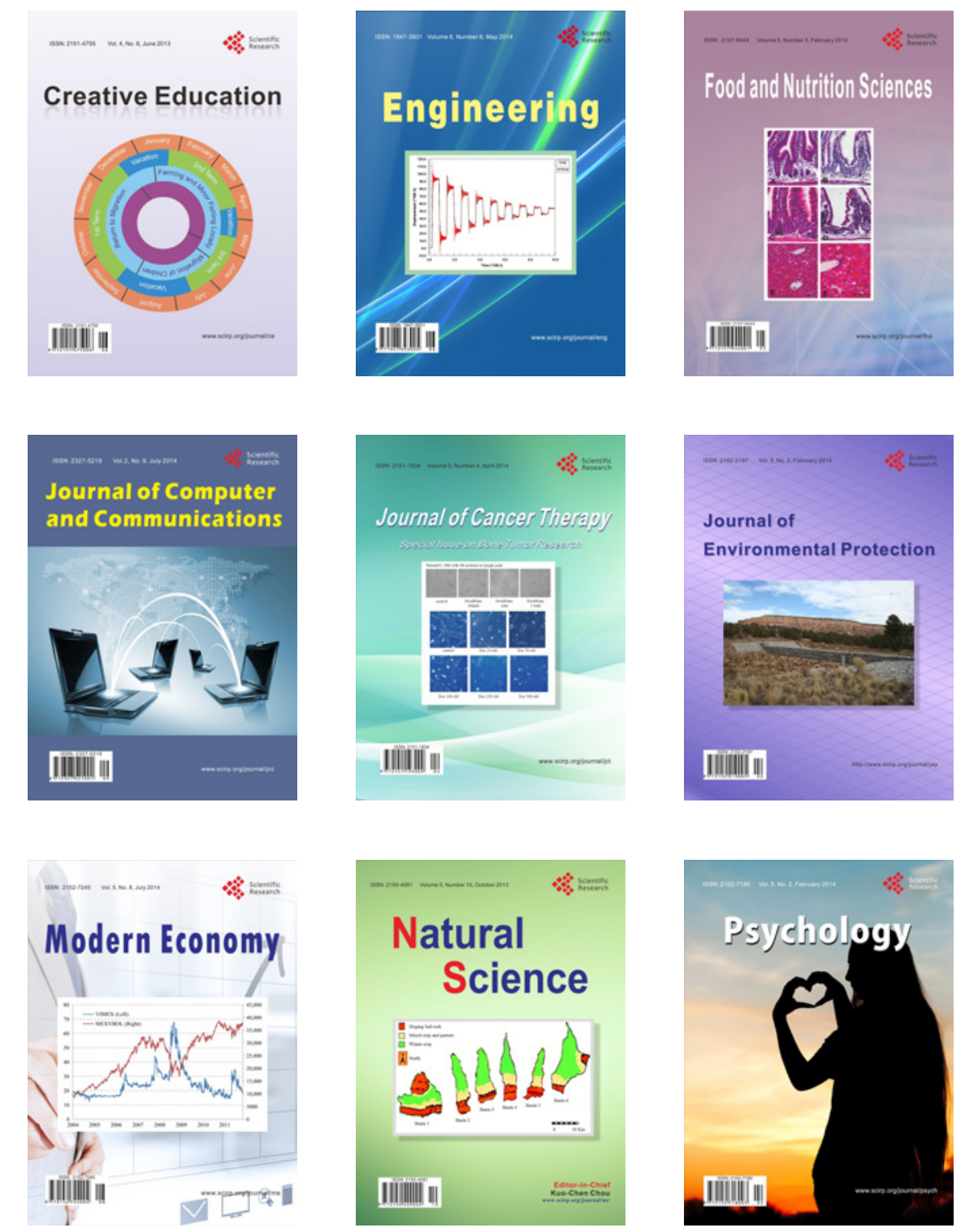